\title{
DISSEMINATION OF FINANCIAL INFORMATION INTO THE PUBLIC SECTOR - AN APPROACH FROM THE VIEW OF THE CENTRAL PUBLIC ADMINISTRATION ENTITIES FROM ROMANIA
}

\author{
Aurelia Ştefănescu ${ }^{1}$ \\ Eugeniu Ţurlea ${ }^{2}$
}

\begin{abstract}
The dissemination of financial information into the sector ensures and develops the transparency and trust of the community into the state entities. In this context, the undertaken qualitative research has as objective to identify the extent to which the entities belonging to the sector of central public administration from Romania disseminate financial information in order to shape a trend of financial transparency. The research results have shown that dissemination through the agency of the official sites of financial information on the basis of complete financial reports is limited. This limitation is shown also in the direction of disseminating financial information on the basis of the individual components of the financial reports. Most of the entities from the central public administration disseminate on the official sites information regarding the budget of revenues and expenses, net monthly wages and activity reports and only two entities do not offer financial information. In temporal terms, the timely extent of the financial information disseminated is relative, it prevails the dissemination of retrospective financial information, while the prospective information is reduced. This survey was foregone by the identification of approaches in respect of the dissemination of financial information into the public sector both from the view of the academic environment, and the professional one, at national and international level. In this respect, the research has shown that adopting the International Public Sector Accounting Standards (IPSAS) into the process of financial reporting ensures and promotes transparency, completeness, credibility, relevance and comparability of financial information into the public sector entities.
\end{abstract}

Key words: dissemination, financial information, transparency, central public administration, Romania

JEL Codes: M41, H83

Introduction

The research premise consists in the existence of the principal-agent type relationships and implicitly, the informational asymmetry between the stakeholders and the public sector entities arising from the potential discretionary interest of the state entities against the stakeholders' interest. In the current context, characterized by the diminution of the financial resources assigned to the public sector entities, the development of the offer of public services supplied to community with implied costs and the quality depreciation of the public services, the limited dissemination of

\footnotetext{
${ }^{1}$ The Academy of Economic Studies, Bucharest, Romania, e-mail: stefanescu.aura@gmail.com

${ }^{2}$ The Academy of Economic Studies, Bucharest, Romania, e-mail: eturlea@yahoo.com
} 
financial information enhance the stakeholders' doubts related to the opportunistic conduct of the state entities. To this, there are added up the neuralgic issues of the national accounting regulations, the limited compliance of the financial reports with the International Public Sector Accounting Standards (IPSAS), the co-existing of regulations and the confusions related to the dissemination of information into the public sector. Taking into account these aspects, the undertaken survey has as objective investigating the extent to which the entities of the central public administration from Romania disseminate financial information.

We consider that such approach shall improve and develop the process of dissemination of the financial information into the sector of the central public administration both from the view of the academic environment, and the professional one, taking into consideration that transparency promotes and consolidates the stakeholders' trust into the state entities.

\section{Research methodology}

The undertaken research is two-dimensional, respectively of interactive and qualitative type. There have been presented the conceptual approaches with reference to the dissemination of financial information into the public sector, both from the perspective of the academic environment, and the professional one by appeal to the interpretative research. This study has been completed by the qualitative research, on the basis of which there have been investigated the official sites of the entities from the central public administration in Romania in order to identify the extent to which these entities disseminate financial information. The survey takes into account the ideas published on this topic into the professional literature, as well as the regulations in the field issued by the national and international regulators.

\section{Conceptual approaches on the financial information dissemination into the public sector}

At conceptual level, the assertions regarding the dissemination of financial information are diversified. In general terms, dissemination is the action of spreading, dispersing, conveying something (http://dexonline.ro/). From the view of the public sector entities, which by their nature have to answer the public's expectations, the financial information dissemination generates transparency and trust. Rawlins (2008) gives the connotation of opening to transparency. In his vision transparency is the deliberate attempt to make available all legally releasable information both positive and negative, having as foundation accuracy, timely, balance and clarity in order to enhance the reasoning ability of publics and hold organizations responsible for their actions, policies and practices.

In opposition, Oliver (2004) considers that into an entity transparency does not limit itself only to the communication with the outside but it also involves positive aspects from the entity's inside activities.

In another approach Rawlins (2008) considers that trust and transparency are significant indicators of the satisfying relationship between the government and the public. A similar idea is supported by Verne (2008) who judges that transparency, completed by ethics are the components of a good governing.

An interesting approach that has as foundation the inter-relationship between transparency, trust, corruption and satisfaction of local community is supported by Park and Blenkinsopp (2011). Considering the role of transparency and trust into the relationship between corruption and citizens' satisfaction, the authors proposed and validated empiriclally, at the local public administration, the 
model according to which transparency and trust play an important role, respectively as moderator and mediator in reducing corruption and improving the satisfaction of local community.

With reference to the International Public Sector Accounting Standards (IPSAS), the survey performed by Pérez and Hernández (2009) showed that the annual financial reports published by the MERCOSUR member countries (Argentina, Brazilia, Paraguay, Uruguay) are not complying with the IPSAS in respect of the dynamic of financial information. Therefore, authors consider there should be made modifications in content in order to improve transparency, coherence and comparison of financial statements in time and space within MERCOSUR.

In terms of information dissemination regarding the financial performance, the results of the research performed by Ştefănescu et al (2011) at the level of the health public system authorities belonging to the European Union member states showed that the extent to which the information was disseminated was reduced due to the fact that there were no explicite and exhaustive requirements.

Dorotinsky and Matsuda (2002), respectively Santiso (2004) approach financial informing in terms of its role. Dorotinsky and Matsuda (2002) assign capital role within the decisional proces to the financial information because it offers the necessary knowledge for the decision taken to be appropriate in achieving the institutional objectives. On the other hand, Santiso (2004) fancies that the improvement of the financial reporting contributes to enhancing the credibility and integrity of public finances and to an efficient management of the public resources.

From the accounting regulating bodies view, into the public sector activating at international level, dissemination and improvement of transparency, quality, responsibility and comparability of financial reporting are circumscribed to the International Public Sector Accounting Standards Board (IPSASB) by drawing up the International Public Sector Accounting Standards (IPSAS). In this respect, complementary to the general financial statements (drawn up for the users who cannot ask for financial information responding to their specific needs of information), built upon IPSAS, IPSASB encourages entities to take up IPSAS also when they develop the financial statements with special purpose (drawn up for managing legislative bodies, with monitoring function).

The coordinates of the general financial statements are described in an exhaustive and comprehensive manner by IPSAS 1 Presentation of financial Statement, respectively by IPSAS 2 Cash Flow Statements. In structural terms, the general financial statements include the following components: a statement of the financial position; a statement of the financial performance; a statement of the modifications within the structure of assets/capitals; a statement of the treasury cash flows; a comparison of the budgetary values and the real ones, either as an additional individual financial statement or as a column of the budget into the financial statements, in case the entity gives its budget to the public; and the notes including a summary of the significant accounting policies and of other explanatory notes.

In terms of the financial reporting objective, this emphasizes the necessity of ensuring and improving dissemination and transparency of the financial information. Thus, according to IPSAS 1 Presentation of financial Statement, the objective of financial reporting is to offer useful information for taking decissions and proving the responsibility of the entity in respect of the resources entrusted to it. Particularly, the financial reports give information on: sources, assignment and use of financial resources; manner in which the entity financed its activities and covered the cash flow; financial statement of the entity and its modifications; useful in evaluating the entity's capacity to get out of debts and meet its commitments, as well as in assessing the entity's performance in respect of the costs of services, efficiency and achievements. Complementarily, the predictive or prospective role of the financial reports offers to the users useful information in 
forecasting the level of resources necessary for the continuous activities, of resources which could be generated by the continuous activities, as well as of the associated risks and uncertainties. In respect of the correlation with the budget, the financial reports give also information to reflect whether the resources have been obtained and used in accordance with the legally adopted budget, respectively the financial limits set up by the corresponding legislative authorities. Also, the utility of the information generated by the financial reports is conditioned by the achievement of the following qualitative features: inteligibility, relevance, credibility and comparability.

In Romania, though the process of developing the public sector accounting was started in 2005 , being a condition to accede the status of full membership of the European Union, there could be noticed it has not gone forward, being at the same level at present.

Orienting the financial reporting towards the IPSAS was limited to the reporting base and the complete or partial definition of several concepts, these concepts not being intercorrelated with the reporting models founded on the professional reasoning and on the freedom to choose. Therefore, the national accounting regulators kept on the hystorical impediments of financial reporting into the public sector, generating confusions and conflicts between the concepts of the retrospective and prospective views. The difficulties of the financial reporting into the public sector entities in Romania are completed by the incomplete or wrong assimilation of cetain ideas from the International Public Sector Accounting Standards (IPSAS) and by the use of various translations for the same concept. Thus, through the empirical research performed, Calu et al (2008) confirms that financial reports do not meet the quality standards recommended by IPSAS, therefore, there must be applied important modifications both in form and content.

Also, when the accounting regulators ignore the qualities of the information given by the financial statements, they limit the informational value of the financial statements at national level. In this respect, the results of the survey performed by Ştefãnescu et al.(2012) on the manner of perceiving the financial performance based on the financial reports by the public hospital managers, show that they consider the balance sheet and the account of budgetary execution are the most relevant reports to disseminate the financial performance, followed by the patrimony earnings account, the treasury flows statement, the situation of modifications ito the structure of assets /capitals. Thus, the survey confirms that the public hospital managers have a wrong view on reporting the financial performance of these entities.

In this context, the issue regarding the financial information dissemination into the national public sector is limited both in terms of the accounting regulations, and those referring to the free access of the public to information of public interest.

The accounting regulations specific to the public sector (OMF 1917/2005) do not approach the idea of dissemination, respectively transparency of the financial information of the public sector entities. The analysis of the aspects regarding the dissemination of the financial information takes into account the identification of the coordinates of the financial information into the public sector entities. In this respect, the analysis of the accounting regulations shows the fact that the regulators did not presented explicitely the connotation of the financial information or their typology. However, by presenting the structure of the financial statement: balance sheet, the account of patrimony earnings, the treasury flow statement, the situation of the modifications into the structure of assets/debts, annexes to the financial statements, the account of budgetary execution, we infer that they generate the sole financial information. In terms of financial statement dissemination, this has compulsory character, it is reduced to the state entities and it takes into consideration either the complete set of financial statements, either some components of it, thus: 
$>$ The public institutions have to submit to the state treasury units where they have open account, the statement of the treasury flows to obtain visa regarding the accuracy of cash payments, balances of cash in bank, if the case, in order to comply with the data into the public institution accounting with those of the state treasury units accounting;

$>$ The public institutions whose managers act as second or third credit managers, submit a copy of the quarterly and annually financial statements to the first credit manager, at the deadlines set by the latter one;

$>$ The ministries, the other speciality structures of the central public administration, other public authorities, autonomous institutions and the administrative territorial units, whose managers act as first credit managers, submit to the Ministry of Public Finance or the general directions of the county public finance bodies, of Bucharest municipe a copy of the quarterly and annually financial statements, at the deadlines set by the latter ones.

The review of the accounting regulations show that an element that generates plus value to the process of disseminating the financial information consists in the declared users of the financial statements, respectively the internal and external users (Government, Parliament, creditors, customers, other users, international financial bodies). If for the internal and external users belonging to the public sector the dissemination of financial information is based on coordinates clearly defined, for customers and stakeholders this is completely ignored.

The limits of the national accounting regulations regarding dissemination of financial information into the public sector are, on the one hand reduced, and on the other hand they are developed by the specific regulations of the free access to public information (Law no.544/2001). In this respect, the information of public interest includes the information related to or resulting from the activitites of public authorities / public institutions, regardless of the support, form or manner of expressing information. According to these regulations, the public institutions have to publish voluntarily the financial and nonfinancial information. The financial information is disclosed by: the financial sources, the budget and the accounting balance sheet. The nonfinacial information consists of: regulations related to organizing and functioning of the entity; organizational structure, departmental duties, functioning hours, entity's schedule of hearings; surnames and first names of the managing persons and of the clerk responsible of the dissemination of public information; entity's contact coordinates: name, headquarters, telephone numbers, fax, e-mail address and address of the internet page; programmes and strategies; list of public interest documents; list of the categories of documents produced and/or managed, according to the law; grievance mechanism in case a person considers itself aggreived in respect of access to the public information asked for. Complementarily, the public sector entities are bound to publish and update annually an informative bulletin and, at least annually, a periodical report of activity. The informative bulletin discloses the financial and nonfinancial information explicitly mentioned by the regulator. For the periodically report of activity, there is no evidence of form, structure, but only the manner of dissemination, respectively in the Official Monitory of Romania, Part III.

The manners the users could access the financial and nonfinancial information are the following: display of the entity's headquarters, or publishing into the Official Monitory of Romania, or into massmedia means, such as in personal publications, like the internet page; consulting information at the entity or public institution's headquarters, in places specially intended for this purpose.

This research shows that in terms of concept the dissemination of financial information into the public sector is an attribute of stakeholders' transparency and trust in respect of its capacity to answer their expectations. Also, the analysis of aspects related to the financial information dissemination at the level of the public sector entities shows that within this process, an important 
role comes to the regulating accounting bodies which have the mission to set up a financial reporting framework ensuring transparency, exhaustiveness, credibility, relevance and comparability to the financial information.

\section{The review of the financial information dissemination into the entities of the central public administration from Romania}

In order to identify the extent to which the financial information and the typology of the financial information are disseminated at the level of the central public administration in Romania, we have turned to investigating the sites of the entities within this sector. In this respect, we took into account the financial information, both real and historical ones. The extent to which the central public administration entities disseminate the financial information, as well as the typology of this information are presented in Annex 1.

The undertaken empirical research shows that at the level of the central public administration from Romania the dissemination extent of the financial information is diminished, implying a limitation of financial transparency into these entities.

In respect of the typology of the published financial information, there can be noticed a wide extent of heterogeneousness, that is mainly reported to the coercive character of regulations and not the entities' voluntarily character. Thus, most of the entities belonging to the central public administration disseminate information on the official sites, offering information on the budget of revenues and expenses, activity reports and net monthly wages.

With reference to the dissemination of financial information through the agency of the complete financial reports, there can be noticed only the Competition Council, The Ministry of Internal Affaires and the Ministry of European Funds that promote financial transparency voluntarily. Some entities (the Ministry of National Defence, the Ministry of Public Finance, the Ministry of Culture and the Ministry of Environment and Climate Changes) are limited to disseminating financial information only through balance sheet, complying thus the imperative stipulations of the regulations in force. Also, other entities (the Constitutional Court, the General Secretariat of the Government) disseminate financial information only through the account of budgetary execution, ignoring the other components of the financial reports. A special case consists in the entities that do not disseminate financial information (the President of Romania, the Senate).

The analysis of the extent of completeness of the disseminated financial information shows a diminished concern of the entities, the Ministry of Internal Affaires, Ministry of European Funds being the sole entities belonging to the central public administration disseminating complementarily the compulsory financial information and the complete financial statements.

\section{Conclusions}

The current research points out that in terms of concept, the dissemination of financial information at the level of the public sector entities promotes transparency and, implicitly, the trust of stakeholders into the state entities.

Reported to Romania, the survey shows a very low extent to which the entities of the central public administration disseminate through the agency of official sites the financial information based on complete financial reports ( 3 entities out of the 23 investigated). Most of the entities belonging to the central public administration disseminate on official sites the information related to the budget of revenues and expenses, the net monthly revenues and the activity reports, and only two entities do not offer financial information. An argument in this respect is given by the assignations explicitely formulated by the national regulators related to the addressees of the 
complete set of financial reports, as well as those related to the typology of information the entities have to disseminate (called public interest information).

In respect of giving financial information by publishing only one component of the financial reports, respectively, balance sheet or account of budgetary execution, the entities show reduced concern for this direction, too. Thus, there can be observed that the informational valences of the other components of the financial reports are completely ignored by the national regulators. We consider that the diminished dissemination of the financial information into the public sector entities is the consequence of limits, confusions and vulnerability of the national accounting regulations, lack of compliance of the financial reports with the International Public Sector Accounting Standards (IPSAS), as well as the co-existing of regulations approaching also aspects related to information dissemination into the public sector. Complementarily, we appreciate this error is the consequence of cognitive gaps into the accounting field of the national regulators.

In temporal terms, the timely extent of the financial information disseminated is relative, it prevails the dissemination of retrospective financial information, but the high degree of the information heterogeneousness limits their comparability.

Also, we consider that the wide spectre of the manners of disseminating the "public interest information", not completed by the correlation of the information typology to the manner of its dissemination, offers to the entities the freedom of options for those manners limiting the facile access to information for stakeholders, reducing thus transparency within the public sector.

As future directions of research, we plan further research to investigate the financial information dissemination at the level of other entities from the national public sector to emphasize to what extent the public sector typology influences the degree of dissemination of the financial information.

\section{References}

1. Calu D.A, Pitulice I.C., Dumitru M., Gorgan C., 2008. Empirical Survey Regarding the Presentation of General Purpose Financial Statements of the Public Sector, Administration and Public Management Review, 1, pp. 105-120

2. Dorotinsky W., Matsuda Y., 2002. Financial Management Reform in Latin America: An Institutional perspective, Revista del CLAD Reforma y Democracia, 23, pp. 1-15

3. Oliver R.W., 2004. What is transparency?, New York, McGraw-Hill

4. Park H., Blenkinsopp J., 2011. L'influence de la transparence et de la confiance dans la relation entre corruption et satisfaction du citoyen, Revue Internationale des Sciences Administratives, no, 2, vol. 77, pp. 251-273

5. Pérez C.C., López Hernández A., 2009. La transparence financiere dans les pays membres du Mercosur, Revue Internationale des Sciences Administratives, no. 1, vol. 75, pp. 185-198

6. Rawlins B.L., 2008. Measuring the relationship between organizational transparency and employee trust, Public Relations Journal, no.2, pp. 1-22, available on-line at http://www.prsa.org/ Intelligence /PRJournal/Documents/Vol2No2/Rawlins.pdf, accessed on 10.09 .2011

7. Santiso C., 2004. IDB lending to budget oversight institutions, CEPAL Review, 83, pp. 161178

8. Ştefănescu A., Țurlea E., Calu D.A., 2012. Difficulties in reporting and disseminating the financial performance into the public sector entities in Romania, Audit Financiar Journal, no. 2 , pp. 25-33 
9. Ştefănescu A., Țurlea E., Calu D.A., 2011. Performance measurement in Romanian public hospitals, African Journal of Business Management, vol.5, no. 2, pp. 552-576

10. Verne D.C., 2008. Ethique et transparece:les deux piliers d'une bonne gouvernance, available on-line at http://www.fgm.usj.edu.lb/files/a32008.pdf accessed on 09.03.2013

11. ***, Explanatory Dictionary of Romanian Language, available on-line at http://dexonline.ro/, accessed on 28.02.2013

12.***, IPSASB, 2009. The International Public Sector Accounting Standards, vol.1, 2, translation, CECCAR Printing House, Bucharest

13. ***, Parliament of Romania, 2001. Law no. 544/2001 related to free access to the public interest information, published into the Official Monitor of Romania no.663 dated 23.10.2001

14. The Chamber of Deputies, available on-line at http://www.cdep.ro/, accessed on 03.03 .2013

15. The Constitutional Court, available on-line at http://www.ccr.ro/, accessed on 03.03.2013

16. The Competition Council, available on-line at http://www.consiliulconcurentei.ro/, accessed on 03.03.2013

17. The General Secretariat of the Government, available on-line at http://www.sgg.ro/, accessed on 03.03.2013

18. The Ministry of Foreign Affairs, available on-line at http://www.mae.ro/ accessed on 03.03.2013

19. The Ministry of Finance, Order of the Public Finance Minister no. 1917/2005 for the approval of Methodological regulations regarding the accounting organization and management of public entities, Accounts planning for the public institutions and the instructions to apply it, published into the Official Monitor of Romania no. 1.18 bis dated 29.12.2005.

20. The Ministry of Agriculture and Rural Development, available on-line at http://www.madr.ro/ro/, accessed on 03.03.2013

21. The Ministry of National Defence, available on-line at http://www.mapn.gov.ro/, accessed on 03.03.2013

22. The Ministry of Public Finance, available on-line at http://www.mfinante.ro/, accessed on 03.03 .2013

23. The Ministry of Justice, available on-line at http://www.just.ro/, accessed on 03.03 .2013

24. The Ministry of Health available on-line at http://www.ms.gov.ro/, accessed on 03.03.2013

25. The Ministry of Internal Affaires available on-line at http://www.mai.gov.ro/, accessed on 03.03 .2013

26. The Ministry of Culture available on-line at http://www.cultura.ro/, accessed on 03.03 .2013

27. The Ministry of Economy available on-line at http://www.minind.ro/, accessed on 03.03 .2013

28. The Ministry of National Education available on-line at http://www.edu.ro/, accessed on 03.03 .2013

29. The Ministry of Labour, Family, Social Protection and Elderly available on-line at http://www.mmuncii.ro/, accessed on 03.03.2013

30. The Ministry of Youth and Sports available on-line at http://www.mts.ro/, accessed on 03.03.2013 
31. The Ministry of Transportation available on-line at http://www.mt.ro/, accessed on 03.03.2013

32. The Ministry of Regional Development and Public Administration, available on-line at http://www.mdrt.ro/, accessed on 03.03.2013

33. The Ministry of European Funds, available on-line at http://www.fonduri-ue.ro/, accessed on 03.03 .2013

34. The Ministry of Environment and Climate Changes, available on-line at http://www.mmediu.ro/, accessed on 03.03.2013

35. The Ministry for the Informational Society, available on-line at http://www.mcsi.ro/, accessed on 03.03.2013

36. The President of Romania, available on-line at http://www.presidency.ro/, accessed on 03.03 .2013

37. The Senat, available on-line at http://www.senat.ro/, accessed on 03.03.2013

Annex 1

Dissemination of financial information into the entities belonging to the central public administration from Romania

\begin{tabular}{|c|c|c|}
\hline $\begin{array}{c}\text { Typology of entities from } \\
\text { the central public } \\
\text { administration }\end{array}$ & Site & Financial information \\
\hline The President of Romania & http://www.presidency.ro/ & - No financial information displayed. \\
\hline The Senate & http://www.senat.ro/ & - No financial information displayed. \\
\hline The Chamber of Deputies & http://www.cdep.ro/ & $\begin{array}{l}\text { - Expenses supported from the budget of the } \\
\text { - Chamber of Deputies to carry out the mandate. } \\
\text { - Expenses supported from the budget of the } \\
\text { Chamber of Deputies to carry out the activity of } \\
\text { the parliamentary offices into the electorate. } \\
\text { - Expenses made with the deputies sent abroad to } \\
\text { carry out temporary missions. } \\
\text { - Allowance granted to the deputies during 2009- } \\
\text { 2013. } \\
\text { - Individual net incomes of the deputies during } \\
\text { 2009-2013. }\end{array}$ \\
\hline $\begin{array}{l}\text { The General Secretariat of } \\
\text { the Government }\end{array}$ & http://www.sgg.ro/ & $\begin{array}{l}\text { - Revenue and expense budgets for the period } \\
\text { 2001-2012. } \\
\text { - Accounts of budgetary execution for the period } \\
2001-2012 \text {. } \\
\text { - Public procurements in } 2012 \text {. } \\
\text { - Net monthly wages related to April } 2010 \text {. }\end{array}$ \\
\hline The Constitutional Court & http://www.ccr.ro/ & $\begin{array}{l}\text { - Account of budgetary execution for } 2011 \text {; } \\
\text { - Summary of the funds assigned on sources and } \\
\text { expense securities for } 2012 \text {. }\end{array}$ \\
\hline The Legislative Council & http://www.clr.ro/ & $\begin{array}{l}\text { - Financial statements on the } 31.12 .2011 \text {; } \\
\text { - Activity reports for the period 1996-2011 } \\
\text { including also the reporting of expenses broken } \\
\text { down on programmes. }\end{array}$ \\
\hline The Competition Council & $\begin{array}{l}\text { http://www.consiliulconcurente } \\
\text { i.ro/ }\end{array}$ & $\begin{array}{l}\text { - Budgets of revenues and expenses for 2007-2012; } \\
\text { - Activity reports for the period 2003-2011 } \\
\text { including also the reporting of expenses broken }\end{array}$ \\
\hline
\end{tabular}




\begin{tabular}{|c|c|c|}
\hline & & down on programmes. \\
\hline $\begin{array}{l}\text { The Ministry of Foreign } \\
\text { Affairs }\end{array}$ & http://www.mae.ro/ & $\begin{array}{l}\text { - Budgets of revenues and expenses for } 2009-2013 \text {. } \\
\text { - Public procurements in } 2012 \text {. }\end{array}$ \\
\hline $\begin{array}{l}\text { The Ministry of Agriculture } \\
\text { and Rural Development }\end{array}$ & http://www.madr.ro/ro/ & $\begin{array}{l}\text { - Budget of revenues and expenses for } 2013 \text {. } \\
\text { - Activity reports for the period 2009-2011 } \\
\text { including in annex } 1 \text { the reporting of the } \\
\text { budgetary assignment. }\end{array}$ \\
\hline $\begin{array}{l}\text { The Ministry of National } \\
\text { Defence }\end{array}$ & http://www.mapn.gov.ro/ & $\begin{array}{l}\text { - Budget of revenues and expenses for 2003-2013. } \\
\text { - Balance Sheet for the period 2006-2012. }\end{array}$ \\
\hline $\begin{array}{l}\text { The Ministry of Public } \\
\text { Finance }\end{array}$ & http://www.mfinante.ro/ & $\begin{array}{l}\text { - Budget of revenues and expenses for } 2013 \text {. } \\
\text { - Balance Sheet on the } 31.12 .2013 \text {. } \\
\text { - Payment statement performed during the years } \\
2012,2013 \text {. } \\
\text { - Public procurement for the period } 2010-2013 \text {. } \\
\text { - Net monthly wages related to the year } 2012 \text { and } \\
\text { to the months January, February } 2013 \text {. }\end{array}$ \\
\hline The Ministry of Justice & $\underline{\text { http://www.just.ro/ }}$ & $\begin{array}{l}\text { - Budget of revenues and expenses for } 2012 \text {. } \\
\text { - Activity reports for the period 2004-2012 } \\
\text { including the evolution of the budget during that } \\
\text { year and reporting of expenses broken down on } \\
\text { programmes. } \\
\text { - Payment statement performed in the year } 2012 \text {. } \\
\text { - Net monthly wages related to the year } 2010 \text {. }\end{array}$ \\
\hline The Ministry of Health & http://www.ms.gov.ro/ & $\begin{array}{l}\text { - Budgets of revenues and expenses for 2007-2016. } \\
\text { - Activity reports for the period 2011-2012 } \\
\text { including also the reporting of expenses broken } \\
\text { down on national health programmes. } \\
\text { - Net monthly wages related to 2010-2013. }\end{array}$ \\
\hline $\begin{array}{l}\text { The Ministry of Internal } \\
\text { Affaires }\end{array}$ & http://www.mai.gov.ro/ & $\begin{array}{l}\text { - Budgets of revenues and expenses for } 2005-2012 \text {. } \\
\text { - Balance Sheet for the period } 2006-2010 \text {. } \\
\text { - Financial statements on the } 31.12 .2011 \text {. } \\
\text { - Net monthly wages related to } 2010-2012 \text {. } \\
\text { - Payment statement performed during } 2012-2013 \text {. } \\
\text { - Public procurements performed and on-going in } \\
\text { 2012-2013. }\end{array}$ \\
\hline The Ministry of Culture & http://www.cultura.ro/ & - Balance Sheet on the 31.12 .2012 . \\
\hline The Ministry of Economy & http://www.minind.ro/ & $\begin{array}{l}\text { - Budgets of revenues and expenses for } 2012 . \\
\text { - Payments performed in } 2012 \text {. }\end{array}$ \\
\hline $\begin{array}{l}\text { The Ministry of National } \\
\text { Education }\end{array}$ & http://www.edu.ro/ & $\begin{array}{l}\text { - Budgetary execution in January-March } 2012 \text {. } \\
\text { - Net monthly wages related to the period } \\
\text { November } 2012 \text { - January } 2013 \text {. }\end{array}$ \\
\hline $\begin{array}{l}\text { The Ministry of European } \\
\text { Funds }\end{array}$ & http://www.fonduri-ue.ro/ & $\begin{array}{l}\text { - Budget of revenues and expenses for the years } \\
2011,2012 \text {. } \\
\text { - Balance Sheet on the } 31.12 .2011 \text {. } \\
\text { - Financial statements on the } 31.12 .2011 \text {. } \\
\text { - Account of budgetary execution on the } \\
31.12 .2011 \text {. } \\
\text { - Net monthly wages related to March } 2012 \text {. } \\
\text { - Public procurement in the year } 2012 \text {. }\end{array}$ \\
\hline
\end{tabular}




\begin{tabular}{|c|c|c|}
\hline $\begin{array}{l}\text { The Ministry } r \text { of } \\
\text { Environment and Climate } \\
\text { Changes }\end{array}$ & http://www.mmediu.ro/ & $\begin{array}{l}\text { - Budgets of revenues and expenses for } 2008-2012 \text {. } \\
\text { - Balance Sheets for the } 2012,2010,2007 \text { financial } \\
\text { exercises. } \\
\text { - Payments performed in } 2012 \text {. } \\
\text { - Activity reports for the period } 2011-2012 \\
\text { including also the reporting of expenses broken } \\
\text { down on programmes. } \\
\text { - Net monthly wages related to March } 2012 \text {. }\end{array}$ \\
\hline $\begin{array}{l}\text { The Ministry of Labour, } \\
\text { Family, Social Protection and } \\
\text { Elderly }\end{array}$ & http://www.mmuncii.ro/ & $\begin{array}{l}\text { - Statistical bulletins within the field of labour and } \\
\text { social protection for the period 2003-2012; } \\
\text { - Statistics related to the period 1938-2013. } \\
\text { - Activity reports for the period 2009-2010 } \\
\text { including also the reporting of expenses broken } \\
\text { down on programmes. }\end{array}$ \\
\hline $\begin{array}{l}\text { The Ministry for the } \\
\text { Informational Society }\end{array}$ & http://www.mcsi.ro/ & $\begin{array}{l}\text { - Payments performed during the period 2011- } \\
2012 \text {. } \\
\text { - Net incomes within the Ministry of } \\
\text { Communication and Informational Society, units } \\
\text { functioning in coordination and under it, as well } \\
\text { as units where MCSI fulfills duties as a majority } \\
\text { stakeholder, achieved in April } 2010 \text {. }\end{array}$ \\
\hline $\begin{array}{l}\text { The Ministry of Youth and } \\
\text { Sports }\end{array}$ & http://www.mts.ro/ & - Budgets of revenues and expenses for 2010-2012. \\
\hline $\begin{array}{l}\text { The Ministry of } \\
\text { Transportation }\end{array}$ & $\underline{\text { http://www.mt.ro/ }}$ & $\begin{array}{l}\text { - Budgets of revenues and expenses for 2009-2012. } \\
\text { - Balance Sheets for the } 2011,2010,2009 \text { financial } \\
\text { exercises. } \\
\text { - Account of budgetary execution on the } \\
31.12 .2011 \text {. } \\
\text { - Public procurements for the period 2010-2011. } \\
\text { - Net monthly wages related to period January - } \\
\text { March } 2012 \text {. } \\
\text { - Activity reports for the period 2005-2009 } \\
\text { including also the reporting of expenses broken } \\
\text { down on programmes. }\end{array}$ \\
\hline $\begin{array}{l}\text { The Ministry of Regional } \\
\text { Development and Public } \\
\text { Administration }\end{array}$ & http://www.mdrt.ro/ & $\begin{array}{l}\text { - Budgets of revenues and expenses for } 2006-2012 \text {. } \\
\text { - Payments performed in } 2012 \text {. } \\
\text { - Activity reports for the period 2005-2011 } \\
\text { including also the reporting of expenses broken } \\
\text { down on programmes. }\end{array}$ \\
\hline
\end{tabular}

Source: Personal design 